Sains Malaysiana 49(12)(2020): 3081-3087

http://dx.doi.org/10.17576/jsm-2020-4912-20

\title{
Mechanical Strength Enhancement of Porous Nanocrystalline-Silicon (pnc-Si) Membrane via Titanium-oxide (Ti-O) Coating
}

(Peningkatan Kekuatan Mekanikal Membran Silikon Nano-kristal Poros (pnc-Si) dengan Penglitup Titanium-oksida (Ti-O))

\author{
Rhonira LatiF*, Muhammad Fahmi JaAFar, Mohd Faizal AZIZ \& Burhanuddin Yeop MaJlis
}

\section{ABSTRACT}

Porous nanocrystalline silicon (pnc-Si) membrane is mainly studied as a blood filtration membrane, mimicking the glomerulus filtration membrane of a human kidney. However, the pnc-Si material itself is not hemocompatible and enormous membrane area to thickness ratio makes the membrane to be easily fractured. Silicon surface modification via titanium-oxide (Ti-O) thin film layer deposition has been proven to be hemocompatible and the presence of Ti-O layer has been numerically studied to give higher membrane flexural strength. In this work, square pnc-Si membranes of $2 \mathrm{~mm} \times 2 \mathrm{~mm} \times 20 \mathrm{~nm}$ size have been fabricated with and without Ti-O layer. Point loading-unloading nanoindentation method has been performed and the membranes'displacement behaviour subjected to point loads is studied. The pnc-Si membranes with Ti-O layer were found to attain higher fracture strength, membrane bending stiffness and average hardness with the increase of $\sim 20, \sim 11$ and $\sim 24 \%$, respectively, compared to bare pnc-Si membranes. The mechanical strength of a free-standing pnc-Si membrane is improved by depositing a Ti-O thin film layer on the membrane structure.

Keywords: Mechanical strength; nanoindentation; pnc-Si membrane; Ti-O thin film

\section{ABSTRAK}

Membran silikon nano-kristal poros (pnc-Si) dikaji sebagai membran penapisan darah, meniru membran penapisan glomerulus buah pinggang manusia. Walau bagaimanapun, bahan pnc-Si itu sendiri tidak hemoserasi dan nisbah keluasan membran kepada ketebalan adalah sangat besar yang menjadikan membran mudah patah. Pengubahsuaian permukaan silikon melalui pemendapan lapisan filem tipis titanium-oksida (Ti-O) telah terbukti hemoserasi dan kehadiran lapisan Ti-O telah dikaji secara analisis berangka bahawa lapisan tambahan ini mampu memberikan kekuatan lenturan membran yang lebih tinggi. Dalam kajian ini, membran pnc-Si yang berbentuk petak dan berukuran $2 \mathrm{~mm} \times$ $2 \mathrm{~mm} \times 20 \mathrm{~nm}$ telah difabrikasi dengan dan tanpa lapisan Ti-O. Kaedah pelekukan nano pemuatan-bongkar titik telah dilakukan dan tingkah laku anjakan membran yang dikenakan daya titik dikaji. Membran pnc-Si dengan lapisan Ti-O didapati mempunyai nilai kekuatan fraktur, kekakuan lenturan membran dan purata kekerasan yang lebih baik dengan peningkatan masing-masing sebanyak $\sim 20, \sim 11$ dan $\sim 24 \%$ berbanding dengan membran pnc-Si tanpa salut. Kekuatan mekanikal membran pnc-Si yang berdiri bebas telah ditambah baik dengan meletakkan lapisan filem nipis Ti-O pada struktur membran.

Kata kunci: Filem nipis Ti-O; kekuatan mekanik; membran pnc-Si; pelekukan nano

\section{INTRODUCTION}

Porous nanocrystalline silicon (pnc-Si) membrane has been researched by many for its incredible small molecules filtration capability with nanometer-scale pores, molecular thinness and straightforward microfluidic integration. The nanoporous membrane has found its role in a wide range of application including ultrafiltration, molecular separation for desalination, optical and biosensors, lab-onchip devices, cellular, and nanoparticles researches. The membrane has previously been studied for gold and protein separation (Gaborski et al. 2010), as cell culture substrates (Agrawal et al. 2010), and for wearable dialysis membrane (Johnson et al. 2013). However, the pnc-Si membrane generally possesses low mechanical strength due to its extreme thinness form with large membrane size area (DesOrmeaux et al. 2014). There is a high possibility of failure due to the fact that the large area membrane can be easily fractured. Extra scaffold support is required to ensure 
this kind of membrane can be reliably and practically used. In blood filtration application, the pnc-Si material has been reported to be not hemocompatible (Ahmadi et al. 2013; Johnson et al. 2013). Silicon materials can introduce significantly high levels of platelet activation.

Titanium with its oxide surface (Ti-O film) is an excellent hemocompatible thin film biomaterial coating which has been used in the development of in-vitro body devices, dental, and orthopaedic applications. Improving the hemocompatibility of these devices via surface modification is essential in order to avoid thrombogenicity in artificial organs (Huang et al. 2003). Pure titanium (Ti) is considered as a reactive metal, in which it will form a thin layer of oxide spontaneously on its surface no matter in liquid or open-air exposure (Steinemann 1991). Only 10 nanoseconds are needed for a titanium thin film layer to grow up to $6 \mathrm{~nm}$ of oxide layer on the surface. The composition of the surface oxide has been shown to be mainly made of titanium dioxide $\left(\mathrm{TiO}_{2}\right)$ and the growth can be further accelerated with the increase of temperature (Kasemo \& Lausmaa 1985; Lausmaa et al. 1990). The grown titanium oxide layer is able to repair itself if damaged and acts as a kinetic barrier against corrosion, making the pure Ti underlayer to be passive and protected (Albrektsson et al. 1983; Parr et al. 1985; Williams 1981). A successful long-term kidney implant for example, requires hemocompatibility, excellent toughness, high strength, corrosion resistance, wear resistance, and fracture resistance.

Previously, we have reported on the influence of $\mathrm{TiO}_{2}$ layer coating on the von Mises stress of pnc-Si membrane (Jaafar et al. 2018). The presence of $\mathrm{TiO}_{2}$ layer has been simulated to reduce the total residual stress within the filtration membrane layer compared to a bare pnc-Si membrane. The addition of $\mathrm{TiO}_{2}$ layer results in a thicker membrane which indirectly made the membrane to have higher flexural strength. In this paper, bare pnc-Si membrane and bilayer pnc-Si membrane with Ti-O thin film layer deposited on top have been fabricated. Pointwise nanoindentation technique is used to investigate and compare the mechanical behaviour of both membranes.

\section{Materials AND Methods}

The schematic process flow to fabricate pnc-Si membrane and bilayer Ti-O/pnc-Si membrane is shown in Figure 1. Starting with a $650 \mu \mathrm{m}$ thick silicon wafer substrate with $200 \mathrm{~nm}$ silicon nitride $\left(\mathrm{Si}_{3} \mathrm{~N}_{4}\right)$ grown on both sides in Figure 1(a), the substrate is cut into 1 by 1 -inch chip and cleaned in acetone/methanol/IPA. Next in Figure 1(b), the $\mathrm{Si}_{3} \mathrm{~N}_{4}$ at the back of the substrate is patterned with four squared membranes, each of size $2 \times 2 \mathrm{~mm}$ using a standard lithography process and etched in buffered oxide etchant (BOE). In Figure 1(c), potassium hydroxide (KOH) was used to etch the $650 \mu \mathrm{m}$ silicon substrates, leaving only the $\mathrm{Si}_{3} \mathrm{~N}_{4}$ layer at the front of the substrate. The obtained $\mathrm{Si}_{3} \mathrm{~N}_{4}$ membrane layer is then sputter-deposited with silicon dioxide $\left(\mathrm{SiO}_{2}\right)$ : amorphous silicon (a-Si): silicon dioxide $\left(\mathrm{SiO}_{2}\right)$ of thickness $15 \mathrm{~nm}: 20 \mathrm{~nm}: 15 \mathrm{~nm}$ as shown in Figure 1(d)-1(e). The substrate is annealed at $800{ }^{\circ} \mathrm{C}$ for a minute in Figure 1(f) to transform the sputter-deposited a-Si thin film layer into a porous nanocrystalline silicon layer (pnc-Si). In Figure 1(g)-1(h), the exposed areas of $\mathrm{Si}_{3} \mathrm{~N}_{4}$ and $\mathrm{SiO}_{2}$ layers are then etched in $\mathrm{BOE}$ at $80{ }^{\circ} \mathrm{C}$, producing suspended pnc-Si membranes. At this stage, some of the pnc-Si membranes broke and destroyed due to the low mechanical strength of the pnc-Si membrane structure, after undergoing a variety of physical and chemical processes. Each of the successfully suspended membrane structure covers an opening of $2 \times 2 \mathrm{~mm}$ on a rigid silicon frame as shown in Figure 2(a). (a)

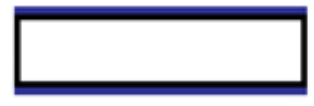

(b)

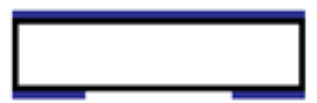

(c)

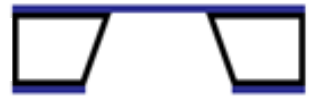

(d)

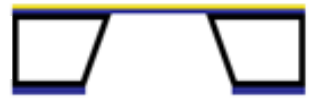

(e)

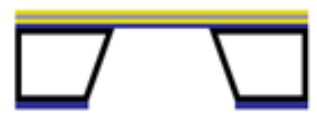

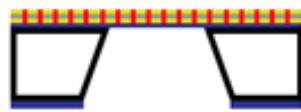

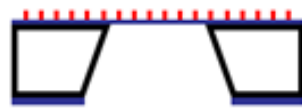

(g)

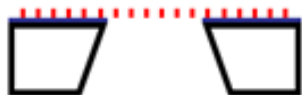

(h)

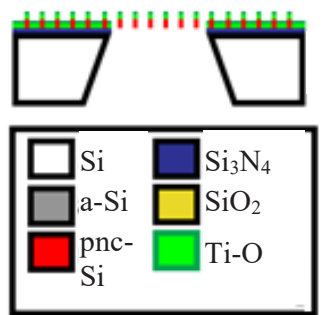

FIGURE 1. Fabrication of pnc-Si membrane and bilayer Ti-O/pncSi membrane 
a)

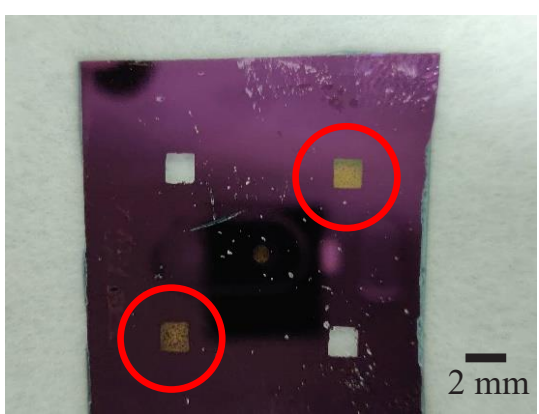

b)

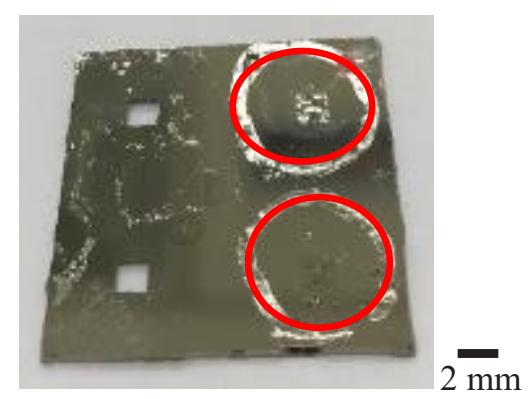

FIGURE 2. a) Two out of four successfully fabricated pnc-Si membranes with $2 \times 2 \mathrm{~mm}$ membrane size area (in red circles), and b) Titanium-oxide (Ti-O) coated pnc-Si membranes (in red circles)

The final step is the deposition of a titanium thin film layer onto the membrane using radio frequency (RF) sputtering technique in Figure 1(i). The sputter deposition process is carried out at $200 \mathrm{~W}$ of sputtering power and 2 mTorr of sputtering pressure, resulting in $\sim 20 \mathrm{~nm}$ of titanium layer thickness. Ti-O is presumably instantly formed on the top surface of the titanium layer due to the employed argon plasma temperature of $\sim 60{ }^{\circ} \mathrm{C}$ in the sputtering chamber during the deposition process of titanium. A bilayer membrane structure made of pnc-Si and Ti-O is obtained (Figure 2(b)).

The mechanical properties of the titanium-oxide coated pnc-Si membrane are inspected by indenting the membrane using nanoindentation tip in Figure 3. Bare pnc-Si membrane without titanium-oxide coating is also measured for performance comparison. For this test, the membrane is attached on the platform before the indenter tip, and then the tip is moved until it reached the membrane surface with a predefined speed and load range. The employed mechanical probe is in the form of a three-sided pyramid, referred to as the Berkovich indenter that deflects the membrane thin film layer under a load rate control. Berkovich tip has Young's modulus and Poisson's ratio of $1141 \mathrm{GPa}$ and 0.07 , respectively. In this study, the resultant membrane displacement according to the variation of point load application is recorded during both loading and unloading phases of indentation. The mechanical response of free-standing square membrane subjected to point loads is investigated using the nanoindentation system.

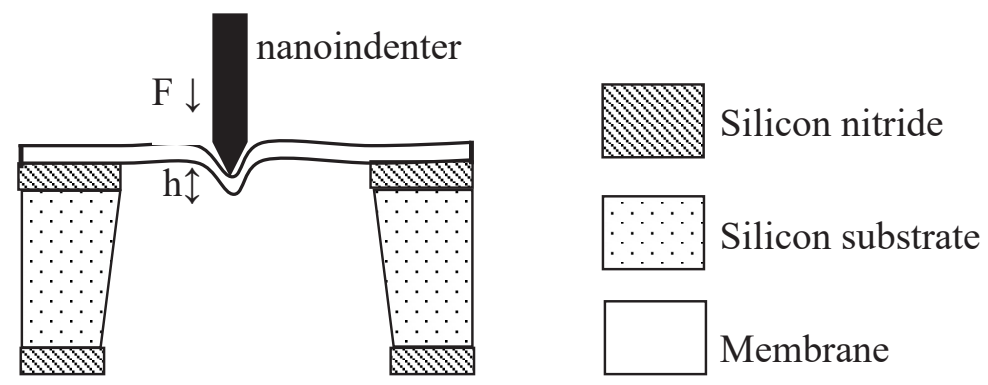

FIGURE 3. Schematic cross section of point deflection method using nanoindenter on a free-standing thin film membrane

\section{RESULTS AND DISCUSSION}

The indentation load is applied close to the central area of the free-standing membrane. The load is increased from 0.03 to $0.39 \mathrm{mN}$ with an increment step of $0.03 \mathrm{mN}$ and similar loading and unloading rate of $0.01 \mathrm{mN} / \mathrm{s}$. At this stage, the load limit is determined for pnc-Si membrane with and without Ti-O thin film layer coating. The fracture point is measured when the membrane is observed to 
break under the applied load. The fracture occurs when the induced stress by the indenter exceeds the biaxial strength of the membrane (Ozaki et al. 2018). The scanning image in Figure 4 demonstrates the condition of the membrane structure at the fracture point load of the indenter tip. We have found that bare pnc-Si membrane was able to withstand up to $0.30 \mathrm{mN}$ load before breaking while titanium-oxide coated pnc-Si membrane reached $0.36 \mathrm{mN}$ load and subsequently broke. The measurement results signify the increase of mechanical strength for pnc-Si membrane with the additional layer of Ti-O thin film.

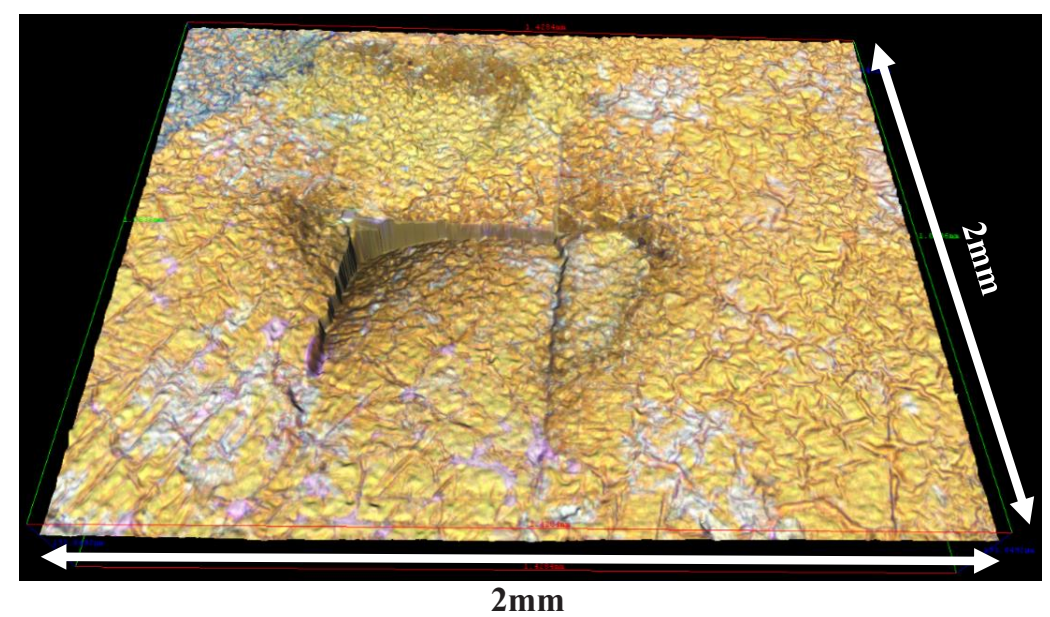

FIGURE 4. Scanning image from surface profiler demonstrating the downward breakage of a membrane structure due to the applied load limit of the indenter tip

In this biaxial flexure testing, the fracture strength or breaking strength of each membrane quantifies the maximum stress it can withstand. The fracture strength is given by $\mathrm{E}_{\mathrm{u}}=\mathrm{F}_{\text {rup }} / \mathrm{A}_{\text {rup }}$ where $\mathrm{F}_{\text {rup }}$ is the maximum force applied that causes the membrane to rupture while $\mathrm{A}_{\text {rup }}$ is the area where force $F_{\text {rup }}$ is applied (Qin et al. 2010). In our study, we approximated $\mathrm{A}_{\text {rup }}$ as the contact area of the indenter tip and membrane at the moment before the membrane breaks. The cross sectional area of the indenter tip is estimated from the highest recorded displacement. Bear in mind that the measured displacement is actually the sum of membrane deflection and the thin film material indentation. For calculation simplification, we assume the measured deflection to be contributed by the indentation of thin film material only. The fracture strength of pnc-Si membrane and titanium-oxide coated pnc-Si membrane is estimated to be 19.1 and $22.9 \mathrm{MPa}$, respectively. Fracture strength indicates the toughness of the whole thin film materials. In this case, the addition of Ti-O thin film layer results in a thicker thin film membrane layer and thus the membrane could withstand larger forces per unit area.

Next, the force-displacement curve for pnc-Si membrane and bilayer Ti-O/pnc-Si membrane is measured at the centre of the membrane structure with a maximum point load of $0.24 \mathrm{mN}$, below their breaking point. The point load is increased from 0.03 to $0.24 \mathrm{mN}$ with similar loading and unloading rate of $0.01 \mathrm{mN} / \mathrm{s}$. Figure 5 shows that both membranes obtained a full loading and unloading curve, with no indication of the membranes being ruptured during the measurement process. In Figure 5(a) for bare pnc-Si membrane, the curve is initiated with a linear slope, before the slope changes beyond $0.2 \mathrm{mN}$ load to become nonlinear. The indenter bends the membrane at the beginning and at this small deflection, only pure bending occurred with a negligible pre-stretching condition, leading to linear behaviour (Qin et al. 2010). After a certain bending displacement, the membrane goes beyond its yield stress, resulting in plastic deformation, as seen by the change of slope. At this stage, the measured deflection is due to membrane bending and material stretching. Membrane stretching dominates over membrane bending at larger displacement by which biaxial tensile stress is introduced (Qin et al. 2010). Higher induced stress can cause higher membrane deflection (Merle et al. 2016). This condition changes the membrane characteristics from linear to nonlinear behaviour, meaning the single point bending indentation has changed into surface stretching indentation. This circumstance can promote membrane fracture if the applied load is large enough. From the maximum load 
with a maximum displacement of $\sim 830 \mathrm{~nm}$, the unloading curve came back closer to the origin position. It seems like the indentation is recovered perfectly. Even though the membrane suffered from plastic deformation at the centre, the other locations on the membrane which are not contacted by the indenter can remain intact and have good elastic recovery (Wang et al. 2007). Therefore, it is postulated that plastic deformation occurred at the centre of the pnc-Si membrane and the membrane possesses good elastic recovery at other areas. (a)

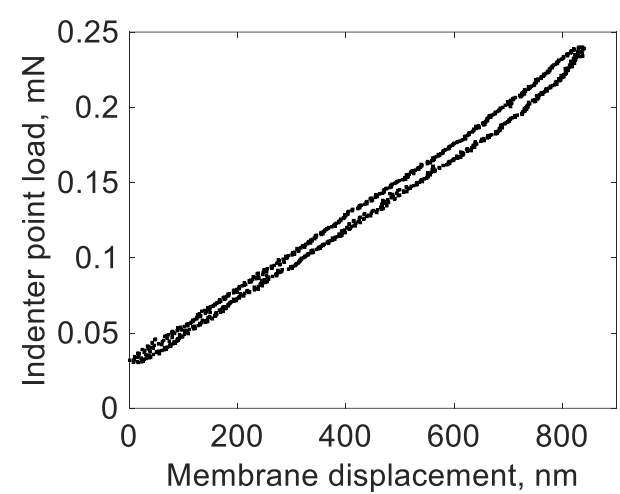

(b)

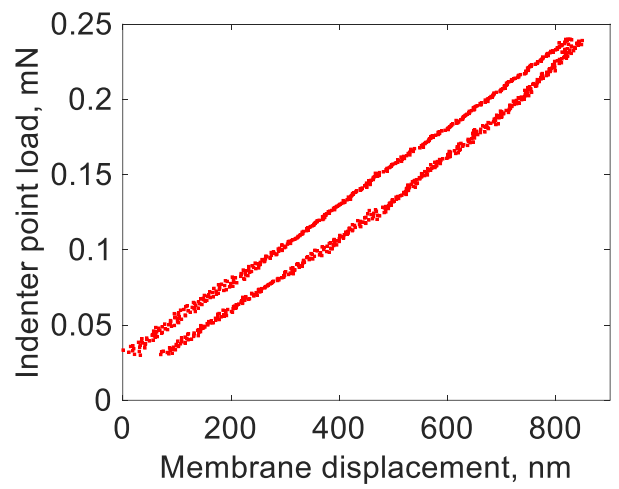

FIGURE 5. Load-displacement data for the indentation process of maximum $0.24 \mathrm{mN}$ load on (a) pnc-Si membrane (b) bilayer Ti-O/ pnc-Si membrane

For the bilayer Ti-O/pnc-Si membrane in Figure 5 (b), there is a linear loading slope to $\sim 820 \mathrm{~nm}$ maximum displacement. No nonlinear plastic deformation behaviour is observed, suggesting only pure bending occurred and no material stretching induced deformation. A creep phenomenon is observed where there is an increase of membrane deflection measured to $\sim 850 \mathrm{~nm}$ when a constant maximum load of $0.24 \mathrm{mN}$ is applied. The deposited top titanium is more prone to creep development compared to the underneath silicon material ( $\mathrm{Li}$ et al. 2016). A returned unloading slope to original load condition is seen but there is still a measured $\sim 70 \mathrm{~nm}$ deflection from the membrane, suggesting poor elastic recovery.

The stiffness of a membrane is quantified as $\mathrm{S}=\mathrm{F} / \mathrm{h}$ where $\mathrm{F}$ is the concentrated transverse load applied at its centre and $\mathrm{h}$ is the membrane's out of plane displacement (Józwik et al. 2004; Poilane et al. 2000; Wang et al. 2007). Membrane bending stiffness is estimated at small deflection with a linear behaviour. An ideal case of the membrane is considered with only pure bending situation. Therefore, the gradient at the loading curve origin is taken as the membrane stiffness (Martins et al. 2009). The stiffness for bare pnc-Si membrane and bilayer Ti-O/pnc-Si membrane is measured to be 239.2 and 267.1 $\mathrm{N} / \mathrm{m}$, respectively. Bare pnc-Si membrane possesses lower stiffness than the ones with Ti-O thin film layer deposited on top. Generally, we found that the pnc-Si membrane deflects more compared to the titanium-oxide coated pnc-Si membrane for the same applied point load. Also, bare pnc-Si membrane enters the nonlinear region first before the titanium-oxide coated pnc-Si membrane. This indicates that the addition of Ti-O thin film layer can let the membrane to bear more load pressure before deflecting, enhancing the mechanical strength of the pncSi membrane. The increase of thickness in the bilayer membrane increases the effective stiffness of the whole structure compared to a monolayer membrane (Wang et al. 2007).

Finally, indentation is performed with a constant load of $0.06 \mathrm{mN}$ along the membrane surface as shown in Figure 6(a) and the average hardness at each indentation point is measured. The applied point load is reduced in order to reduce the membrane stiffness and thus, ensuring the membrane to work in a linear region. The loading and unloading rate were fixed to $0.01 \mathrm{mN} / \mathrm{s}$. In Figure $6(\mathrm{~b})$, as the indenter tip moves across the membrane, the measured hardness is higher at the membrane edge and then decreases as the tip reaches the central membrane position before increases again as it moves away from the centre. Similar hardness trend behaviour is observed for both bare and Ti-O thin film coated pnc-Si membranes. Generally, the lack of fixed boundary support from the membrane edge makes the membrane hardness to become lower in the middle. Furthermore, the membrane strength 
is also declining in line with the carried-out indent process due to the fact that the repeated application of load pressure from the indenter tip causes nano-fretting of the membrane that wears down its strength. (a)

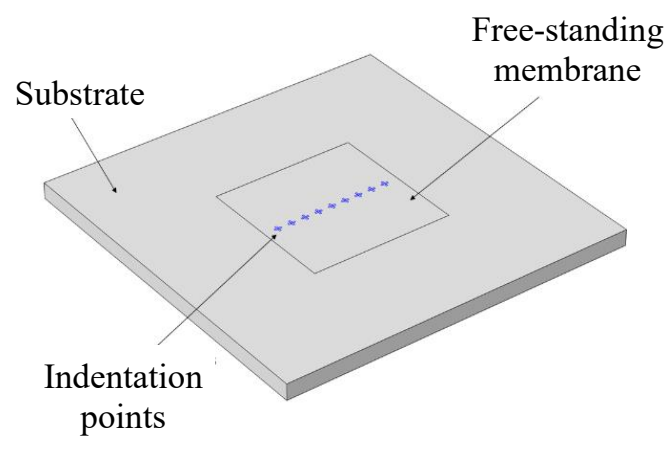

(b)

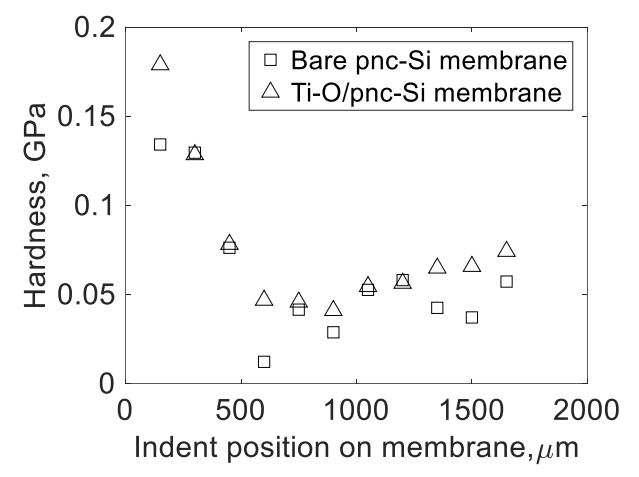

FIGURE 6. (a) Schematic representation of the indentation points across the membrane, and (b) Hardness measurement by the indenter across the membranes

Average hardness is estimated by averaging the hardness values measured across the free-standing membrane area. The average hardness for a pnc-Si membrane structure is measured to be $\sim 60.9 \mathrm{MPa}$. A higher average effective hardness of $\sim 75.8 \mathrm{MPa}$ is measured from the pnc-Si membrane structure with a Ti-O thin film layer. This measurement also supports our previous result finding, that the presence of Ti-O thin film coating can increase the mechanical strength of the thin film membrane system. Effectively, the harder thin film layer requires larger load to drive the indenter into the same membrane deflection. By increasing the total thickness of the membrane, higher flexural strength is achieved, which can also be indirectly equated with the membrane yield strength (Fang et al. 2010). Based on our previous simulation study, the addition of $\mathrm{TiO}_{2}$ layer on the pnc-Si membrane has contributed to the increase in mechanical strength, assisted the membrane to accommodate greater load pressure and decreased dramatically the von Mises stress induced in the membrane. We have suggested that an additional $15 \mathrm{~nm}$ layer of $\mathrm{TiO}_{2}$ is sufficient to obtain a considerably low von Mises stress value while at the same time being able to produce sufficient pore size for molecular transport (Jaafar et al. 2018).

\section{CONCLUSION}

Point loading-unloading at the centre and across the free-standing area of a square pnc-Si membrane with and without Ti-O thin film layer deposited on top have been carried out using a nanoindenter. Membrane displacement results have shown positive increment in fracture strength, membrane bending stiffness and average hardness. The enhancement of mechanical strength in pnc-Si membrane via the addition of Ti-O thin film layer increases the reliability of the membrane in withstanding high-pressure working environment, as well as being hemocompatible at the same time. However, the additional thin film layer sputter-deposited on the membrane structure that increases the overall membrane thickness can reduce its permeability performance. Further investigation is necessary to find the optimum value of the Ti-O thin film layer thickness which will eventually offer the desired permeability and provide sufficient mechanical strength to the fabricated filtration membrane.

\section{ACKNOWLEDGEMENTS}

The work was supported by HICOE-AKU-95 grant funded by the Ministry of Higher Education, Malaysia. The authors would also like to acknowledge the contributions of Universiti Kebangsaan Malaysia (UKM) through its research grant with code GGPM-2016-032.

\section{REFERENCES}

Agrawal, A.A., Nehilla, B.J., Reisig, K.V., Gaborski, T.R., Fang, D.Z., Striemer, C.C., Fauchet, P.M. \& McGrath, J.L. 2010. Porous nanocrystalline silicon membranes as highly permeable and molecularly thin substrates for cell culture. Biomaterials 31(20): 5408-5417.

Ahmadi, M., Gorbet, M. \& Yeow, J.T.W. 2013. In vitro clearance and hemocompatibility assessment of ultrathin nanoporous 
silicon membranes for hemodialysis applications using human whole blood. Blood Purification 35(4): 305-313.

Albrektsson, T., Brånemark, P.I., Hansson, H.A., Kasemo, B., Larsson, K., Lundström, I., McQueen, D.H. \& Skalak, R. 1983. The interface zone of inorganic implants in vivo: Titanium implants in bone. Annals of Biomedical Engineering 11(1): 1-27.

DesOrmeaux, J.P.S., Winans, J.D., Wayson, S.E., Gaborski, T.R., Khire, T.S., Striemer, C.C. \& McGrath, J.L. 2014. Nanoporous silicon nitride membranes fabricated from porous nanocrystalline silicon templates. Nanoscale 6(18): 10798-10805.

Fang, D.Z., Striemer, C.C., Gaborski, T.R., McGrath, J.L. \& Fauchet, P.M. 2010. Methods for controlling the pore properties of ultra-thin nanocrystalline silicon membranes. Journal of Physics: Condensed Matter 22(45): 454134.

Gaborski, T.R., Snyder, J.L., Striemer, C.C., Fang, D.Z., Hoffman, M., Fauchet, P.M. \& McGrath, J.L. 2010. Highperformance separation of nanoparticles with ultrathin porous nanocrystalline silicon membranes. ACS Nano 4(11): 6973-6981.

Huang, N., Yang, P., Leng, Y.X., Chen, J.Y., Sun, H., Wang, J., Wang, G.J., Ding, P.D., Xi, T.F. \& Leng, Y. 2003. Hemocompatibility of titanium oxide films. Biomaterials 24(13): 2177-2187.

Jaafar, M.F., Latif, R. \& Majlis, B.Y. 2018. Influence of titanium oxide coating on mechanical properties of porous nanocrystalline silicon membrane. 2018 IEEE International Conference on Semiconductor Electronics (ICSE). pp. 49-52.

Johnson, D.G., Khire, T.S., Lyubarskaya, Y.L., Smith, K.J.P., DesOrmeaux, J.P.S., Taylor, J.G., Gaborski, T.R., Shestopalov, A.A., Striemer, C.C. \& McGrath, J.L. 2013. Ultrathin silicon membranes for wearable dialysis. Advances in Chronic Kidney Disease 20(6): 508-515.

Józwik, M., Delobelle, P., Gorecki, C., Sabac, A., Nieradko, L., Meunier, C. \& Munnik, F. 2004. Optomechanical characterisation of compressively prestressed silicon oxynitride films deposited by plasma-enhanced chemical vapour deposition on silicon membranes. Thin Solid Films 468(1-2): 84-92.

Kasemo, B. \& Lausmaa, J. 1985. Metal selection and surface characteristics. In Tissue-Integrated Prostheses, edited by Brånemark, P-I., Zarb, G. \& Albrektsson, T. Chicago: Quintessence Publishing Co.

Lausmaa, J., Kasemo, B. \& Mattsson, H. 1990. Surface spectroscopic characterization of titanium implant materials. Applied Surface Science 44(2): 133-146.
Li, Y., Chen, Y., Liu, J.R., Hu, Q.M. \& Yang, R. 2016. Cooperative effect of silicon and other alloying elements on creep resistance of titanium alloys: Insight from first-principles calculations. Scientific Reports 6: 30611.

Martins, P., Delobelle, P., Malhaire, C., Brida, S. \& Barbier, D. 2009. Bulge test and AFM point deflection method, two technics for the mechanical characterisation of very low stiffness freestanding films. The European Physical Journal Applied Physics 45(1): 10501.

Merle, B., Nicholson, K.S., Herbert, E.G. \& Göken, M. 2016. An improved method for point deflection measurements on rectangular membranes. Materials \& Design 109: 485-491.

Ozaki, T., Koga, T., Fujitsuka, N., Makino, H., Hohjo, H. \& Kadoura, H. 2018. Biaxial flexure testing of free-standing thin film membrane with nanoindentation system. Sensors and Actuators A: Physical 278: 48-59.

Parr, G.R., Gardner, L.K. \& Toth, R.W. 1985. Titanium: The mystery metal of implant dentistry. Dental materials aspects. Journal of Prosthetic Dentistry 54(3): 410-414.

Poilane, C., Delobelle, P., Lexcellent, C., Hayashi, S. \& Tobushi, H. 2000. Analysis of the mechanical behavior of shape memory polymer membranes by nanoindentation, bulging and point membrane deflection tests. Thin Solid Films 379(12): 156-165.

Qin, H., Jin, J., Peng, X. \& Ichinose, I. 2010. Mechanical properties of free-standing single layers of metallic nanocrystals. Journal of Materials Chemistry 20(5): 858-861.

Steinemann, S. 1991. The properties of titanium. In Oral Implantol: Basics, ITI Hollow Cylinder System, edited by Schroeder, A., Sutter, F. \& Krekeler, G. Stuttgart: Thieme.

Wang, T.H., Fang, T.H., Kang, S.H. \& Lin, Y.C. 2007. Nanoindentation characteristics of clamped freestanding $\mathrm{Cu}$ membranes. Nanotechnology 18(13): 135701.

Williams, D.F. 1981. Fundamental Aspects of Biocompatibility. Boca Raton: CRC Press.

Institut Kejuruteraan Mikro dan Nanoelektronik

Universiti Kebangsaan Malaysia, Jalan Bangi

43600 Bangi, Selangor Darul Ehsan

Malaysia

*Corresponding author; email: rhonira@ukm.edu.my

Received: 19 August 2020

Accepted: 27 August 2020 